\title{
Taxonomy of Camptotheca Decaisne
}

Dpen Access

\author{
Shiyou $\mathrm{Li}^{*}$
}

National Center for Pharmaceutical Crops, Arthur Temple College of Forestry and Agriculture, Stephen F. Austin State University, Nacogdoches, TX 75962, USA

\begin{abstract}
Based on the phenotypic, micromorphological, and genetic analysis, three species are recognized in the genus Camptotheca Decaisne: C. acuminata Decaisne, C. lowreyana Li, and C. yunnanensis Dode. Camptotheca acuminata consists of three varieties: var. acuminata, var. tenuifolia Fang et Soong, and var. rotundifolia Yang et Duan. Camptotheca lowreyana has three newly developed high CPT-yielding cultivars, namely 'Katie', 'CT168', and 'Hicksii',
\end{abstract}

Keywords: Camptotheca acuminata Decaisne, Camptotheca acuminata var. tenuifolia Fang et Soong, Camptotheca acuminata var. rotundifolia Yang et Duan, 'Katie', 'Camptotheca Decaisne, Camptotheca lowreyana Li, Camptotheca yunnanensis Dode, CT168', 'Hicksii', taxonomy.

\section{SPECIES DEFINITION}

The species is the fundamental category of the taxonomic hierarchy. Scientific names of species are binomials consisting of the genus name and the species epithet. However, species concepts have long been the focus of debate among population geneticists, ecologists, taxonomists, and philosophers. Definitions are various and even individual in many cases. Actually, there are gaps between theoretical and practical work at the species level. In other words, defining species as a category and delimiting species in practice are two distinct issues of "the species problem" [1].

Biologists and geneticists often adopt one of the following concepts. The biological species concept (BSC) developed by Ernst Mayr has been widely recognized, at least in theory. Mayr stated that "species are groups of interbreeding natural populations that are reproductively isolated from other such groups." [2,3]. The BSC emphasizes reproductive isolation of species. Genetic species concept assumes that the biological factors of gene flow and reproductive isolation are operative, but the way to define species is by a measure of the genetic differences or distance among populations or groups of populations [4]. Evolutionary species concept argues an evolutionary species is a lineage evolving separately from others and with its own unitary evolutionary role and tendencies [4].

However, these concepts are not actually adopted or rejected by most taxonomists as impracticable. In contrast, plant taxonomists often used traditional morphological or taxonomic species concept (also called the Linnaean, classical, or classical phenetic species concept) in the practice of classification of plants. For example, Cronquist recognized that species are the smallest groups that are consistently and persistently distinct, and distinguishable by ordinary means [5]. Other taxonomists may emphasize a number of significant differences or major morphological discontinuities. Only a few taxonomists state the use of the BSC in their

*Address correspondence to this author at the National Center for Pharmaceutical Crops, Arthur Temple College of Forestry and Agriculture, Stephen F. Austin State University, Nacogdoches, TX 75962, USA; Tel: 936-4682071; Fax: 936-468-7058; E-mail: lis@sfasu.edu classification treatment. In fact, to most plant species, type specimens and their morphological differences are emphasized; and population variations and genetic and development data are rarely studied. Most taxonomists would believe that the morphological differences used for species delimitation do indeed reflect similar degrees of interbreeding and reproductive isolation [4]. In today's taxonomy, the more evidence to support, the better the classification.

Camptotheca Decaisne has been recognized as a monotypic genus since 1873 when the genus was established by Joseph Decaisne. Recently, the genus has been systematically treated. As a result, C. yunnanensis Dode is now recognized as a distinct species, and C. lowreyana, a new species, has been described [6]. Species should be morphologically distinct. At least two correlated qualitative characters in reproductive and vegetative organs (e.g., flowers, fruits, leaves, and branches) can be constantly employed in the delimitation of a species within a genus. Interbreeding is important, but not the only criterion to delimit a species. The "good species" should also be supported by anatomic and molecular data. Thus, species is a useful basic unit in plant management and conservation. Variations within species should be recognized. Populations that have morphological differences insufficient to be distinguished as species but with different ranges or habitats should be recognized as subspecies. Those having similar ranges or habitats should be classified as varieties. Although no single species concept can be applied to all plant species, the same concept should be used within a genus. In this monographic treatment, we used diagnostic (correlated) phenotypic characters (e.g., leaf shape, flower size, fruit color and texture) integrated with developmental, anatomic, and genetic data to delimit species. The data lead to identification of three species and two varieties in Camptotheca: C. acuminata Decaisne (var. acuminata, var. rotundifolia Yang et Duan, and var. tenuifolia Fang et Soong), C. lowreyana Li, and C. yunnanensis Dode.

In this taxonomic treatment of Camptotheca, investigations have been made in the following fields: (1) study of literature in different languages; (2) examination of over 2,000 sheets of specimens (including types) deposited in major herbaria of the world; (3) years of field investigations 
and collections in the natural range of the species; (4) 6-year observation of over 5,000 plants representing 100 accessions and 35 provonences in the greenhouse and the field (from seeds to mature trees); (5) measured major morphological (flowers, fruits, seedlings, mature plant branches and leaves) characters of all herbarium specimens and selected living specimens; (6) measured micromorphological traits of pollen, fruit, and leaf surfaces under light microscope, SEM, and remote sensing technology; (7) conducted genetic variation analysis of different populations by RAPD markers; and (8) analyzed content of CPTs of different populations. As a result of the phenotypic variation analysis of 80 characters, the following qualitative and quantitative characters are recognized as diagnostic in the species:

1. Habit: deciduous (C. acuminata and C. lowreyana), semi-deciduous (C. yunnanensis)

2. Leaf shape: oval (C. acuminata), cordate (C. lowreyana), elliptic (C. yunnanensis)

3. Glandular trichome (lower leaf surface): obelliptic $(C$. acuminata), pandurate (C. lowreyana), obelliptic $(C$. yunnanensis)

4. Flower bract length (mm): 2.0-2.5 (C. acuminata), 1.52.0 (C. lowreyana)

5. Flower petal length (mm): 2.0-2.5 (C. acuminata), 1.21.5 (C. lowreyana)

6. Fruit color (mature, dry): red-brown (C. acuminata), gray-brown (C. lowreyana), gray (C. yunnanensis)

7. Fruit disc thickness (mature, dry): thick (C. acuminata), thin (C. lowreyana and C. yunnanensis)

8. Fruit surface texture: rugose (C. acuminata), smooth and lustrous (C. lowreyana and C. yunnanensis)

9. Fruit length (mean): $22 \mathrm{~mm}$ (C. acuminata), $30 \mathrm{~mm}(C$. lowreyana), $20 \mathrm{~mm}$ (C. yunnanensis)

10. Cotyledon shape and mean length: lanceolate and $36 \mathrm{~mm}$ (C. acuminata), lanceolate and $34 \mathrm{~mm}$ (C. lowreyana), linear and $27 \mathrm{~mm}$ (C. yunnanensis)

11. Cotyledon venation type and mean vein number (each side): pinnipalmate and 3 (C. acuminata and C. yunnanensis), pinninerved and 7 (C. lowreyana)

12. Hypocotyl color: green ( $C$. acuminata and $C$. lowreyana), red (C. yunnanensis)

13. DNA markers. Our RAPD analyses indicate that each of three species can be identified by DNA markers: $C$. $a c u$ minata has the lowest genetic diversity, while $C$. lowreyana has the highest genetic diversity. The DNA markers are relatively stable among populations within each species.

\section{DESCRIPTION OF GENUS CAMPTOTHECA}

Camptotheca Decaisne in Bull. Soc. Bot. France XX:157 (1873). -TYPE: Camptotheca acuminata Decaisne, 1873.

Deciduous or semi-deciduous trees. Bark is light gray and smooth at young ages (usually $<5$ years old), brown with reddish-tinged scales and even furrowed into flat ridges at maturity. Twigs are gray-green, and young ones are red or green and are usually pubescent with diaphragmed pith. Leaves are simple, alternate, papery, pinnately veined, oval, ovaloblong to oblong-elliptic, rounded, ovate, cordate, slightly pubescent, acuminate, entire or serrate (one year-old seedlings). The lower leaf surface has simple unicellular hairs and unicellular glands. Stomata are anomocytic according to the arrangement of surrounding cells, 20-35 $\mu \mathrm{m}$ long and 10-25 $\mu \mathrm{m}$ wide with 4-8 subsidiary cells; and glandular trichomes on lower leaf surface are 30-50 $\mu \mathrm{m}$ long; glandular trichomes on the upper leaf surface are globose or subglobose. Usually, two sessile flowers form a cyme, and 1530 cymes form a dense global head (1.5-2.0 cm in diameter). Two to ten global heads are arranged in a terminal or axillary raceme-like or panicle-like compound inflorescence. Flowers in heads on the upper part of the compound inflorescence are bisexual and bloom first. Those on the lower part are male or sometimes bisexual. Bracts are three, pubescent, smaller in male flowers than those in bisexual flowers. The calyx is cup-form, 5 toothed with cliliate margins. Petals are 5 valvate, light green, and pubescent. Ten white stamens grow in two whorls, with the outer whorls maturing first. Filaments are slender, glabrous; anthers are apicifixed and 4-locular. Camptotheca, like Nyssa [7], is stenopalynous with very little variation among species (unpublished data). Pollen is 3colporate, suboblate, obtuse-triangular in polar view, 29-38 $\mu \mathrm{m}$ (polar axis) $\times 33-54 \mu \mathrm{m}$ (equatorial axis), sexine punctitegillate. Colpi are not very distinct; and colpi margins are provided with nexinous thickenings [8]. At pollen shedding, each sporangium dehisces inwards without forming two cavities. The suture of the anthers is spiral. A ring-like nectary exists between the stamens and pistil. The pistil consists of three (two) carpels with one glabrous two- or three-lobed style. The ovary is inferior, unilocular, with one ovule per locule. Flowers bloom in May-August. Fruits are samaralike, sessile, with persistent disc. Usually 40-65 fruits are grouped in a globose heads (apitula), 12-43 mm long and 3.5-10 mm wide, glossy in fresh, red-brown, gray or graybrown, wrinkled or smooth when dry. The fruit ripens in September-November. Trees begin to bear fruit at 5-10 years of age. Hypocotyl is green or red before appearance of primary leaf. Cotyledons are simple, opposite, pinnipalmate or pinninerved, lanceolate or linear. Three species and two varieties are recognized in the genus. All are native to southern China. The key and comparison of the species and varieties are as follows (Table 1, Fig. (1), and Fig. (2)).

\section{KEY TO SPECIES AND VARIETIES}

1a. Bark thick, deeply furrowed into ridges at maturity; leaf cordate or ovate with the widest point below the blade middle, usually $12-19 \mathrm{~cm}$ long and $7-10 \mathrm{~cm}$ wide, with 14-18 lateral veins on each side, with greenish and lustrous leaf lower surface; glandular trichomes on the lower leaf surface pandurate, 44-52 $\mu \mathrm{m}$ long; leaf stomata larger (mean: $29.33 \times 20.08 \mu \mathrm{m}$ ) and more frequent (mean: 263.20 stomata $/ \mathrm{mm}^{2}$ ), outer stomatal rim with outer rings of striae, with more subsidiary cells (usually 5 or 6); flower bracts $1.5-2.0 \mathrm{~mm}$ long; petals $1.2-1.5 \mathrm{~mm}$ long; fruits, 26-32 (22-43) mm long, gray-brown, nonwithered, smooth, and lucid when dry, with two thin discs; hypocotyl is green before primary leaf appears, cotyledon lanceolate, pinninerved with 6-8 lateral veins on each side .....C. lowreyana. 
Table 1. Morphological comparison of taxa in Camptotheca (---- No data available. L - blade length; Wm - blade maximum width; W1 - blade width at $1 / 5$ from the base; W2 - blade width at $1 / 5$ from the apex; $\mathrm{Lm}$ - distance of the widest point from the base along the main vein. * referring to the hypocotyl color before the primary leaf appears).

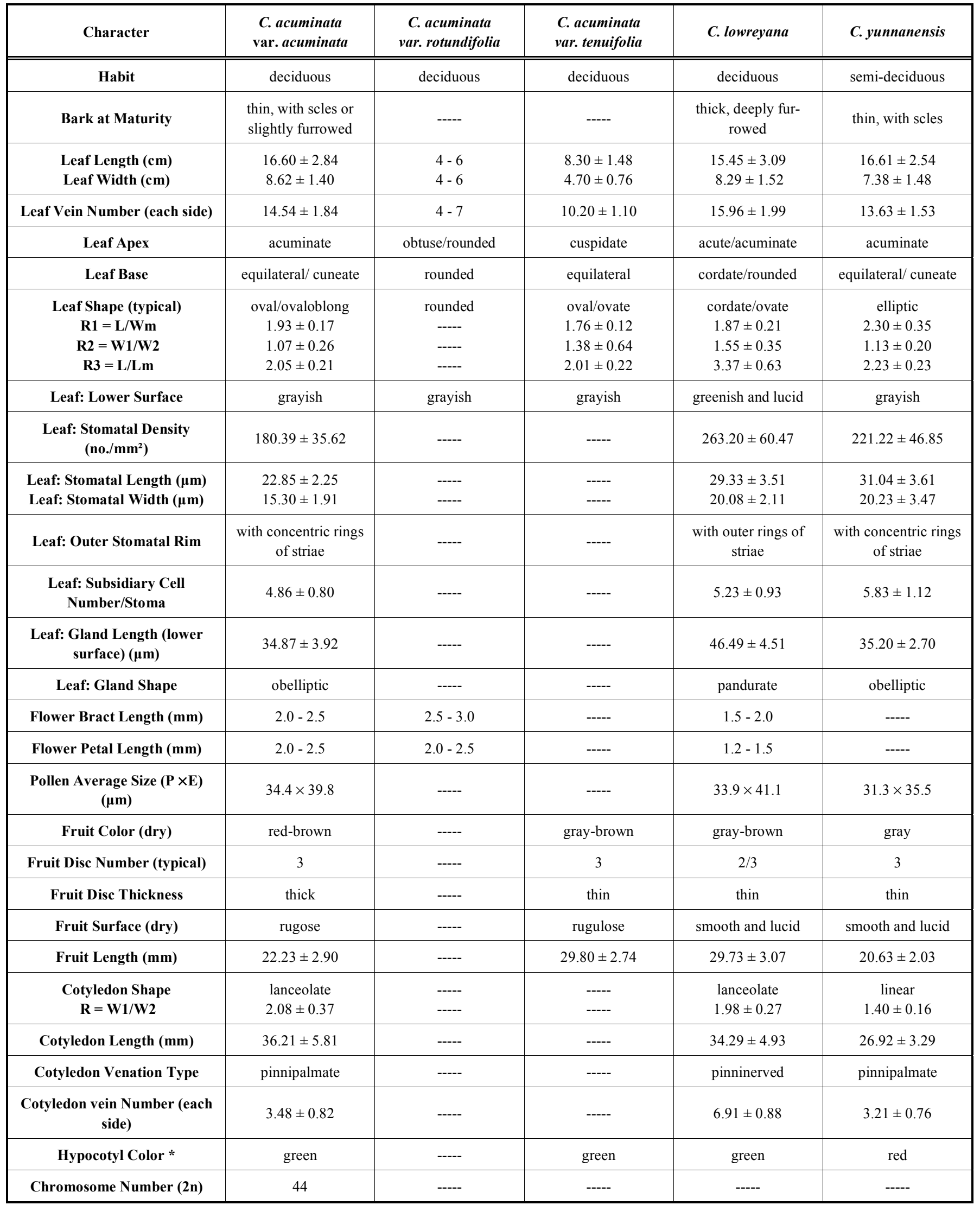




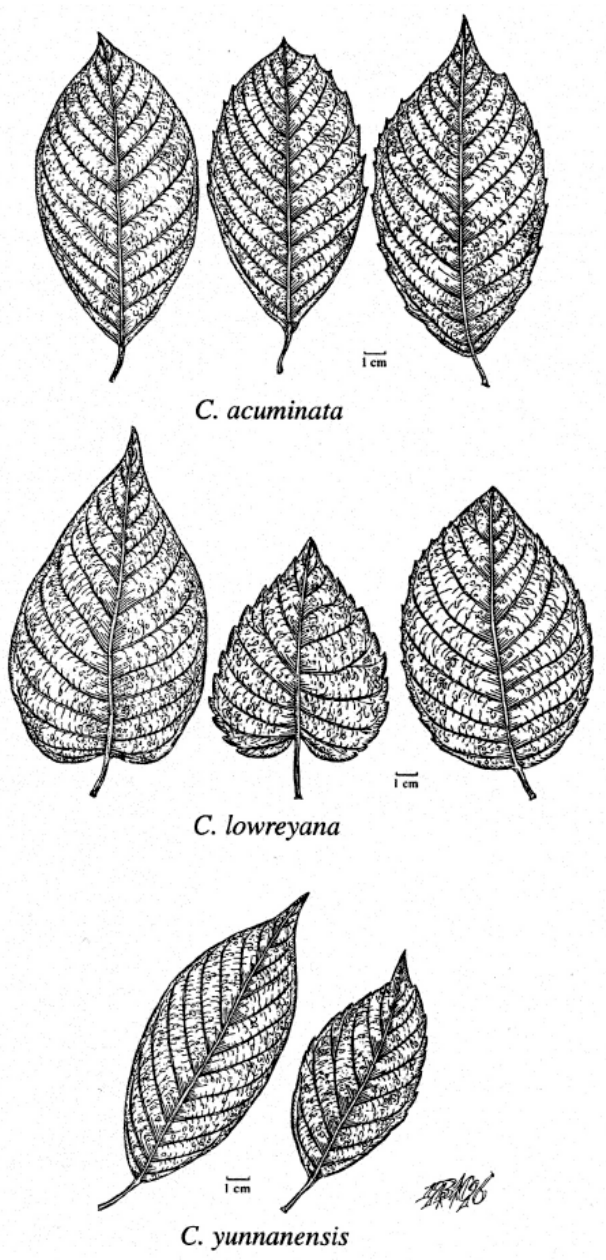

Fig. (1). Typical leaves of different species of Camptotheca Decaisne [6].

1b. Bark thin, brown with reddish-tinged scales or slightly furrowed into flat ridges at maturity; leaf oval, ovate, rounded, or elliptic with the widest point at the middle of the blade, usually with grayish leaf lower surface; glands on the lower leaf surface obelliptic, less than $40 \mu \mathrm{m}$ long, outer stomatal rim with concentric rings of striae; flower bracts $>2.0 \mathrm{~mm}$ long; petals $>2.0 \mathrm{~mm}$ long; fruits $20-25$ (30) $\mathrm{mm}$ in length, usually with three discs; cotyledon pinnipalmate or pinnerved with 2-5 lateral veins on each side

2a. Leaf semi-deciduous, elliptic, usually $14-19 \mathrm{~cm}$ long and 6-9 cm wide, with 12-15 lateral veins on each side; stomata larger (mean: $31.04 \times 20.23 \mu \mathrm{m}$ ) and more frequent (mean: $221.15 / \mathrm{mm}^{2}$ ); fruits gray, non-withered, smooth, and lucid when dry; hypocotyl red before primary leaf appears; cotyledon linear, pinnipalmate with 2-4 lateral veins on each side ............. . yunnanensis

2b. Leaf deciduous, oval or rounded; stomata smaller (mean: $<30 \times 20 \mu \mathrm{m})$ and less frequent (mean: $<200 / \mathrm{mm}^{2}$ ); fruits red-brown or gray-brown, thin-winged, withered, and rugose or rugulose when dry; hypocotyl green before primary leaf appears; cotyledon linear, pinnipalmate with 2-4 lateral veins on each side
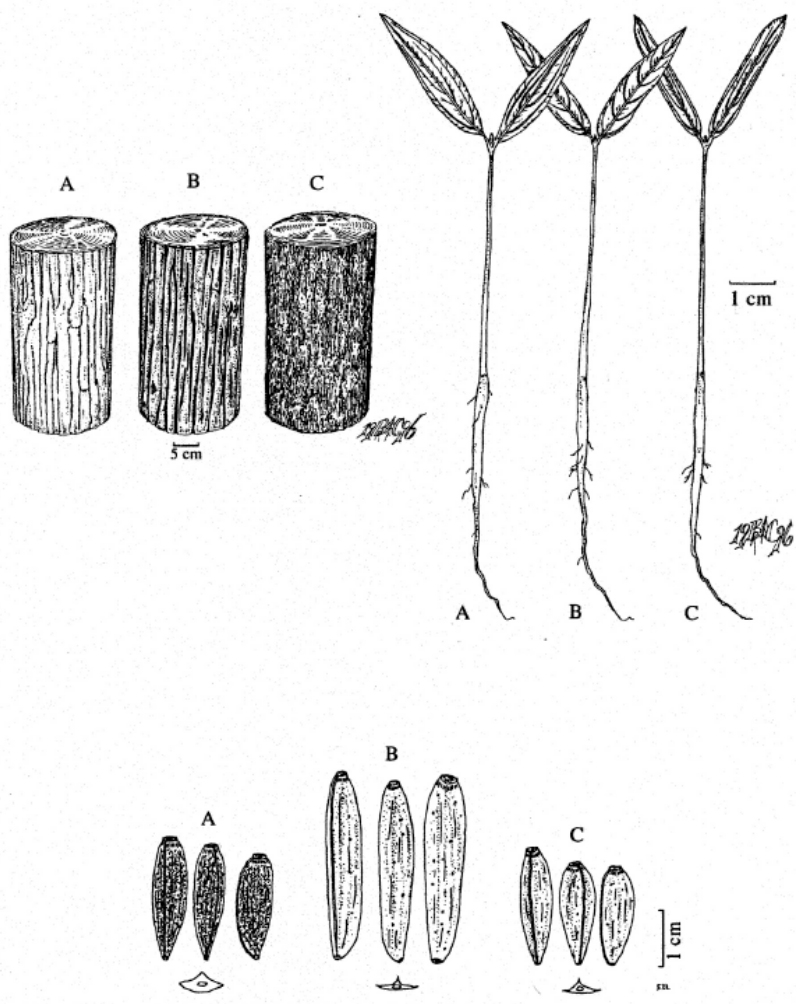

Fig. (2). Bark, fruit, and seedling comparisons of different species of Camptotheca Decaisne (A: C. acuminata; B: C. lowreyana; C: C. yunnanensis) [6].

3a. Leaf round or sub-round, 4-6 cm long, 4-6 $\mathrm{cm}$ wide, with 4-7 lateral veins on each side; leaf anatomic data not available; bark, fruits, and cotyledon not seen . . . . . . . . ............... acuminata var. rotundifolia

3b. Leaf oval, larger with more lateral veins

4a. Leaf oval, occasionally ovaloblong to oblong-elliptic, acuminate, usually $14-20 \mathrm{~cm}$ long, $7-10 \mathrm{~cm}$ wide, with 13-17 lateral veins on each side; fruits red-brown with thick disc ...... C. acuminata var. acuminata

4b. Leaf oval or ovate, usually 7-10 cm long, 4-6 cm wide, with 9-11 lateral veins on each side; bark, leaf stoma, flower, and cotyledon data not available ............ .C. acuminata var. tenuifolia

\section{GENERAL DESCRIPTIONS}

1. Camptotheca acuminata Decaisne in Bull. Soc. Bot. France XX. 157 (1873); Baillon in Hist. Pl. VI. 282 (1877); Franchet in Nouv. Arch. Mus. Paris II. 8:241, t. 9 (P1. David. $2: 59$, t. 9) (1886); Hemsley in Jour. Linn. Soc. XXIII. 346 (1888); Diels in Bot. Johrb. XXIX. 504 (1900); Dode in Bull. Soc. Bot. France LV. 650 f. b (1908); Wanger in Engl. Pflanzenr. 41 (IV. 220a): 17, f. 3 (1910); Wilson in Pl. Wilsonianae IV. 254-255 (1914); Hu and Chun in Ic. P1. Sinica- 
rum t. 41 (1927); Lee in For. Bot. China 856-858, pl. 242, 243 (1935); Fang in Icon. Pl. Omeiens. 1: Pl. 1(1942); Steward in Man. Vas. Pl. Low. Yangtze Val. China 271, f. 258 (1958); Eyde in J. Arnold Arbor. XLIV. 1:18, 20 (1963); Ann. in Fl. Sichuanica Tom. 1:314-315, pl. 120 (1981); Fang and Zhang in Fl. Reip. Pop. Sin. 52(2):144-146 (1983); Xu in Icon. Arbor. Yunnanicorum 816, 818, f. 431 (1990); Li and Adair in Camptotheca acuminata Decaisne, 45-52, f. 612 (1994). Qin and Phengklai in Flora of China 13:300 (2007) [9]. TYPE: China. Jiangxi: Lushan, M. I'Abbe David $866(\mathrm{P})$.

This species was first described by Joseph Decaisne, Director of the Jardin Des Plantes, Paris in 1873. The type specimen was collected by Father Armand David in Lushan, Jiangxi Province, during his 1868-1870 exploration of China. Two varieties, var. tenuifolia Fang et Soong and var. rotundifolia Yang et Duan were described in 1975 and 1988, respectively. Because either the type tree or the type specimen was destroyed and no other collections were made after the publications, the present authors recognized these two varieties according to the original description and single type specimen (var. tenuifolia) or the original description only (var. rotundifolia).

1a. Camptotheca acuminata Decaisne var. acuminata (Figs. 1-3).

Common name: $\underline{\mathrm{Xi}} \underline{\mathrm{Shu}}$ (Chinese happytree).

Camptotheca acuminata var. acuminata is a polygamomonoecious deciduous tree. It can reach $40 \mathrm{~m}$ in height and $120 \mathrm{~cm}$ in stem diameter at breast height under favorable conditions. The trunk is usually without branches for $30 \mathrm{~m}$ above the ground. When immature, bark is light gray and smooth, and brown with reddish-tinged scales or slightly furrowed into flat ridges at maturity. Twigs are gray-green, young ones red or green and usually pubescent. Leaves are oval, ovaloblong to oblong-elliptic, slightly pubescent, acuminate, equilateral or cuneate, 14(10)-20 (35) cm long and 7(5)-10(20) cm wide, lateral veins 11-17 (19) on each side, lower surface grayish, with $1.5-5.0 \mathrm{~cm}$ petiole. Bracts are triangular ovate; and 2.5-3.0 $\mathrm{mm}$ long. Pollen is 3-colporate, suboblate, obtuse-triangular in polar view, 34.4 (28.6-40.2) $\mu \mathrm{m}$ (polar axis) $\times 39.8(34.5-42.5) \mu \mathrm{m}$ (equatorial axis), sexine punctitegillate. Colpi are not very distinct, margins with nexinous thickenings (Erdtman 1966). Fruits are usually three thick-winged, 19-25 (12-28) $\mathrm{mm}$ long and 3.5-8.0 $\mathrm{mm}$ wide, red-brown, withered, and rugose when dry, with 3-8 $\mathrm{cm}$ peduncle. Hypocotyl is green before primary leaf appears. Cotyledons are lanceolate $2-4 \mathrm{~cm}$ long, about $1 \mathrm{~cm}$ wide, pinnipalmate, with 2-3 (4) lateral veins on each side. The species is diploid with $2 \mathrm{n}=44$ [10].

\section{Distribution and Ecology}

While historically widespread and found throughout southern China at the beginning of the 20th century, it appears at present that $C$. acuminata var. acuminata now grows naturally only in Guangdong, Guangxi, Guizhou, Hunan, and Yunnan Provinces. According to our survey in 1995, wild $C$. acuminata var. acuminata is no longer available in Sichuan, Hunan, and most of the eastern provinces. The wild trees were found growing at elevations up to $2,700 \mathrm{~m}$ in the Ailo Mountains of Yunnan Province in the early 1980's (Zhong- shu Yao, pers. comm. 1995). Individual trees measured up to $40 \mathrm{~m}$ in height and $120 \mathrm{~cm}$ in basal diameter. The lowest temperature recorded in these mountains is $-10^{\circ} \mathrm{C}$. While at present only a few young trees can be found, their location at such high elevations indicates that these individuals are cold tolerant and may provide the seed source for plantation development in the northern subtropical region. This seems to confirm a need to protect the current wild tree resources in China in order to maintain the broadest possible genetic pool for the variety.

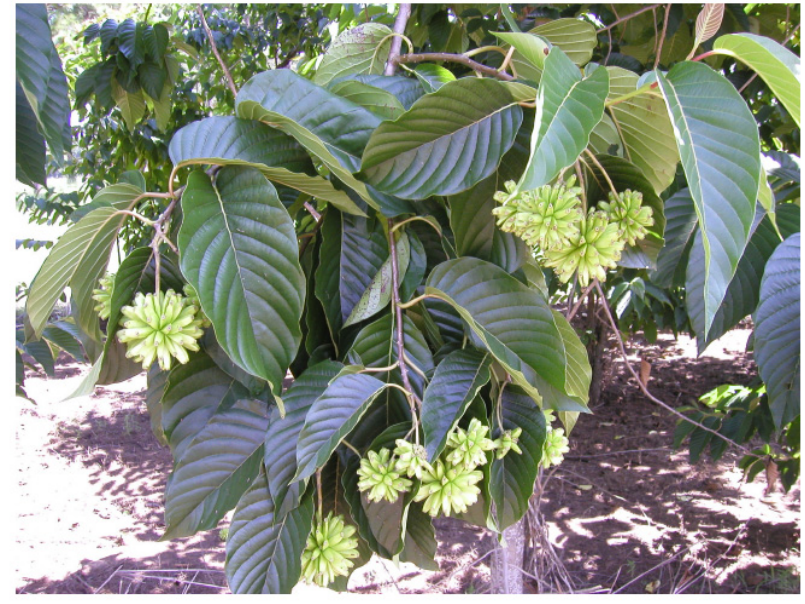

Fig. (3). Camptotheca acuminata Decaisne cultivated in Nacogdoches, Texas, USA.

In China, C. acuminata var. acuminata is one of 84 major afforestation species (varieties). Due to rapid growth in early years, it has been widely planted in the "four-sides" south of the Yangtze River. Sichuan has a long history of plantations and a plentiful supply of trees. However, prior to 1950, foursides plantations in China were established only in the Sichuan Basin (Mianyang, Deyang, Shenfang, Fengzhou, and Anxian). Since 1950, the tree has been planted in the entire eastern half of the province from Yunyang in the east to Tianquan in middle of the province, and from Pingwu in the north to Gulan in the south [11]. Even pure plantations (some 1-5 ha) have been established in the low hills region of the province in the last ten years. Camptotheca acuminata var. acuminata grows well from $400 \mathrm{~m}$ to $1,200 \mathrm{~m}$ in elevation, but appears to perform best below $700 \mathrm{~m}$ elevation. In the Sichuan basin, however, the species is found at elevations up to $1,500 \mathrm{~m}$ where the tree occasionally suffers frost damage.

Toward the end of the 19th Century, a French missionary in the Bailu Community, Pengzhou City planted seedlings along a stream. In this favorable environment, the largest trees observed in southern China are among this group of 70 trees. In our 1995 survey we measured the largest in the stand, $40 \mathrm{~m}$ tall and $80 \mathrm{~cm}$ in diameter at breast height. The elevation is $900 \mathrm{~m}$ with annual precipitation of $1,300 \mathrm{~mm}$, average annual temperature of $12^{\circ} \mathrm{C}$, and the minimum annual temperature of $0^{\circ} \mathrm{C}$. At present, the trees are protected by the local government as "Old Trees". In Yunnan, there are an estimated 2 million mature $C$. acuminata var. acuminata, trees and annual seed production reaching 1,000,000 $\mathrm{kg}$ (dry weight). 


\section{Specimen Citation}

CHINA. Anhui (Anhwei): Buqiu Zhong 4441 (BISC, cultivated); Huangshan, Arboretum of Forestry Institute, 440 m, 3 Aug 1973, Zhou-Xu-Pan-Cheng 365 (PE, cultivated); Huangshan, 1,200 m, 9 Oct 1933, M. Chen 1330 (PE). Fujian (Fukien): Dehua, villageside, 1959, Kemin Wu 60235 (BISC); Jianyang, Huangkeng Guilin, 400 m, 5 Sep 1979, Wukao Team 1210 (BISC, cultivated); Longyan, Ruchang Lin 2045 (BISC); Taining, Jiaoxi, 18 Jun 1979, Mingshen Li 598 (BISC); Tongan, Tingxi Tree Farm, 45 m, 15 Aug 1965, South China Team 556 (BISC); Xuancheng, Jingli Zhou 95010 (ASTC, seeds only, cultivated). Guangdong (Kwangtung): 22 Dec 1927, Woon Young Chun 5834 (A); Dinghu, School of Agriculture, 60 m, 17 Aug 1980, Guangqi Ding and Guoliang Shi 785 (BISC, cultivated); Guangning, Gushui, 850 m, 3 Mar 1995, Shiyou Li and Wanli Zhang 95410051 (ASTC, NEFI, cultivated); Guangzhou, Aug 14 1981, H. G. Yip 431 (BISC, BM); Guangzhou, Arboretum of Zhongshan University, 28 Jun 1950, Shaoqing Chen 336889 (BISC, cultivated); Huaiji, Dakengshan Tree Farm, 1,270 m, 4 Mar 1995, Shiyou Li and Wanli Zhang 95410065 (ASTC, NEFI, cultivated); Koung Tse Paai, 150 m, 22 Jul 1921, F. A. McClure 6546 (A); Liannan, Jin Keng Huang Dong, 11 Sep 1958, Feixiang Tan 283868 (BISC); Lianshan, Shangshuai, 600 m, 9 Jul 1958, Feixiang Tan 58684 (BISC, SZ); Lianshan, Yaoan, 750 m, 2 Nov 1958, Feixiang Tan 60175 (BISC, SZ); Nanxiong, Zhumu, 300 m, 23 Jun 1958, Liang Deng 6523 (BISC); Renhua, road to Yihua, 600-700 m, 29 Sep 1958, Liang Deng 7778 (SZ); Ruyuan, 1971, Guangdong Team 71-442 (BISC). Guangxi (Kwangsi): S. K. Lau 28686 (E); C. Wang 41116 (A), 41273 (A); Ching Sai, 21 Aug 1935, S. P. Kao 55524 (A); Dayao, Shanliang, valley, 810 m, 19 Jun 1958, Yinkun Li 400393 (BISC); Donglan, Dachou, 7 Jun 1957, Zhi Huang 43510 (KUN, BISC, cultivated); Duan, Jiacheng, field side, 18 Jul 1957, Yinkun Li P01658 (BISC, cultivated); Guangnan, woods, 5 Oct 1935, Xipeng Ma 55854 (BISC); Guilin (Kweilin), 220 m, 1979, P. P. Wan and K. S. Chow 79088 (E, K, MO, BM, PE, cultivated); Guilin, Liangfeng, 10 Jul 1948, Zhinong Deng 13596 (BISC); Guilin, Haiyang Shan, 8-12 Jul 1937, W. T. Tsang 27800 (A, US, cultivated); Guilin, Haiyang Shan, 13-19 Jul 1937, W. T. Tsang 27824 (US, cultivated); Guilin, Mawang Shan, 4-19 sep 1937, W. T. Tsang 28212 (US, cultivated); Guilin, Haiyang Shan, 4-19 Sep 1937, W. T. Tsang 28212 (BISC, cultivated); Hechi, Kougang, woods, Yinkun Li P01528 (BISC, WUK); Jingxi, road to Biaolin, 21 Aug 1935, Xipeng Ma 55524 (BISC, cultivated); Jinxiou, Liuji, woods, 530 m, 1 Nov 1981, Dayaoshan Team 12254 (BISC); Jinxiou, Liuxiang, 700 m, 2 Nov 1981, Dayaoshan Team 13133 (BISC); Jinxiou, Luomeng, 820 m, 27 Sep 1981, Dayaoshan Team 11133 (BISC); Lingui, 29 Oct 1953, Yuebang Xu 10592 (WUK); Lingchuan, Lingze Temple, W. T. Tsang 27824 (A, BISC); Lingyun, Yuhong, woods, 17 Jul 1937, Xinqi Liu 28686 (BISC); Longlin, Yancha, 1,000 m, 2 Nov 1957, Zhaosai Zhang 10715 (KUN, BISC); Longsheng, San Men Da Di, 15 Oct 1958, Hongfu Tan 701109 (WUK); Longsheng, Sanmen, 500 m, 8 Aug 1957, Piling Wang 3665 (HNNU); Luchuan (?), 23 Oct 1928, Ying Jiang (Ying Tsiang) 1429 (A); Luochen, 1939, Wen Chen 84157 (BISC, cultivated); Nandan, Wuyi, mixed hardwoods, 7 Aug 1937, Zhi Huang 41273 (BISC); N.-I. Shan, 250 m, 23 May 1928,
Renchang Ching 5214 (A); Rugui, Dongling, $750 \mathrm{~m}$, Anonymous 8858 (HNNU); Xingan, Huajiang, 31 Aug 1937, Jixin Zhong (Z. S. Chung) 83670 (BISC); Xingan, Simen Qian, woods, 19 Jun 1936, Jixin Zhong 81815 (A, BISC); Xinning, 300-350 m, 13 Aug 1917, H. Handel-Mazzetti 2215 (A); Yunghsien, Chang An, Oct 23 1933, A. N. Steward and H. C. Cheo 1180 (A, BM); Zhiyuan, town, 17 Aug 1958, Zhaoyu Chen 51948 (BISC, cultivated). Guizhou (Kweichow): Anhui, roadside, $960 \mathrm{~m}, 11$ May 1960, Zhisong Zhang et al. 2302 (BISC); Liping, Qutuan, $560 \mathrm{~m}$, Yongcang Li 9133 (BISC, cultivated); Pachai, 800 m, Jul 29 1930, Ying Jiang (Ying Tsing) 6116 (BM, C); Sanhoa, 700 m, 5 Aug 1930, Ying Jiang 6286 (A, E, K, US); Tushan, 400 m, 20 Aug 1930, Ying Jiang 6487 (A); Tushan, 500 m, 9 Sep 1930, Ying Jiang 7070 (P); Xingren, Yingong, 600 m, 19 Aug 1960, Zhisong Zhang 8190 (BISC); Xingren, Guolongchang, 1,300 m, 18 Aug 1960, Guizhou Team 7827 (BISC, WUK); Zhexiang (Che Kia Tsing), 12 Jun 1913, M. PAbbe Esquirol 1338 (P). Hainan: Wanning, Hainan Botanical Garden, 5 Apr 1961, Shaqing Chen 309824 (BISC, cultivated). Henan (Honan): Jigongshan, Railroad Forestry Farm, 23 Aug 1956, Xiangqing Zhang 20365 (PE, cultivated). Hubei (Hopeh): 1885-1888, A. Henry 7606 (A, BM, K); Western Hubei, Aug 1900, E. H. Wilson 1681 (A, E). Hunan: Changsha, Yaolu Shan, 760 m, 22 Jun 1948, Y. Liu 14 (PE, cultivated); Changsha, Yaolu Shan, 12 Jun 1956, Qinglian Chen 118 (BISC, cultivated); Hengshan, Nanyao, 5 Oct 1953, Hunan Team 787 (PE, BISC, cultivated); Hengshan, Nanyao, Shaoyi Ho 150166 (BISC, cultivated); Hengshan, Nanyao, 150 m, Jun 1956, Guoxiong Zhang 591 (SZ, cultivated); Sanglin, roadside, 1,200 m, 4 Jul 1958, Linhan Liu 9283 (KUN, WUK); Wugang, 350-500 m, 5 Aug 1917, H. Handel-Mazzetti 2198 (A); Xinning, Ziyunshan, 850 m, 8 Sep 1984, Zenyu Li et al. 1075 (K). Jiangsu (Kiangsu): Nanjing, Botanical Garden, Fangxun Liu 60235 (BISC, cultivated); Nanjing, Zhongshanmenwai, 75 m, 1980, Gensheng Zhou (K. S. Chow) 80271 (BM, E, K, PE, cultivated); Nanjing, Zijinshan, 28 Aug 1951, Fangxiong Liu 1322 (PE, cultivated). Jiangxi (Kiangsi): 2 Aug 1907, E. H. Wilson 1544 (US); 1935, S. P. Ko 55854 (A); Chongyi, Wenying, roadside, 480 m, Minxiang Nie 9017 (KUN); Dayu, park, 330 m, 25 Aug 1958, Jie Xiong 2091 (PE, cultivated); Guangchang, town, 10 Oct 1958, Qiming Hu 5439 (PE, BISC, cultivated); Guixi, 120 m, 20 Aug 1958, Ying Jiang and Shushen Lai 4049 (KUN); Guling, 24 Oct 1922, Woon Young Chun 4311 (A); Giling, 700 m, 25 Jul 1928, C. Y. Chiao 18701 (US); Huichang, Fucheng, 9 Jul 1958, Qiming Hu 3326 (PE); Huichang, Shiba, 19 Jun 1958, Qiming Hu 2850 (KUN, PE); Jian, School of Agriculture, 27 Jul 1981, Qinshen Xu 29 (BISC, cultivated); Jinggangshan, 180 m, 8 Aug 1907, E. H. Wilson 1544 (A); Jinggangshan, Ciping, 900 m, 22 Aug 1965, Shushen Lai 4685 (KUN, BISC); Jiujiang, 800 m, 6 Jul 1921, H. H. Hu 1090 (A); Jiujiang (Kewkiang), foot of Lushan, flower part received in Mar 1873, fruit part received Aug 1893, T. L. Bullock 31 (K); Kiennan, Sai Hang Cheung, Jul 1934, S. K. Lau 3941 (A, BM, US); Kiennan, Sai Hang Cheung, 28-30 Aug 1934, S. K. Lau 4252 (A, BM, US); Lushan, 1868, M. I'Abbe (D. A.) David 866 (Isotype: P); Lushan, 25 Jun 1922, N. K. Ip 1052 (E); Lushan, Aug 1934, H. H. Hu 2348 (PE), 2532 (A); Lushan, Temple side, 2 Sept 1932, H. C. Cheo 229 (E, K); Lushan, 700-600 m, 2 Jul 1933, H. H. Chung and S. C. Sun 248 (A); Lushan, Botanical 
Garden, 23 Aug 1951, Heng Zhou 775 (BISC, cultivated); Lushan, Qixiansi, 28 Aug 1974, Kejian Guan 74439 (PE); Lushan, Xioufengsi, 27 Jun 1955, Binggui Li 275 (BISC); Ningdu, roadside, 14 Oct 1958, Lushan Botanical Garden Team 5453 (KUN, PE, cultivated); Ruijin, High School, 30 Jul 1958, Qiming Hu 3981 (PE, cultivated); Shangyu, 11 Sep 1971, Jiangxi Team 658 (PE); Shicheng, Chengping, 15 Sep 1958, Qiming Hu 4929 (KUN, PE); Suiyi, 4 Jun 1958, Qiming $\mathrm{Hu} 2332$ (PE); Tonggu, Dashiduan, 25 Sep 1963, Shushen Lai 3758 (PE, KUN); Wuling, Luoping, 400 m, 28 Jun 1963, Shushen Lai 2829 (KUN); Wuyu, Luoping, 400 m, Shushen Lai 2829 (PE); Yongfeng, Xiaojia, 2 Jul 1984, Anonymous 841343 (BISC); Zhixi, Shixia, 8 Jul 1958, Shushen Lai 3325 (KUN). Shaanxi: Changan, Nantong, Experimental Station of Shaanxi Forestry Research Institute, 29 Dec 1996, Shiyou Li, Katie Northrup, David Creech, and Dehui Zhang CN-SX-C-96-1229001 (ASTC, cultivated, seeds); Xian, Botanical Garden, 28 Dec 1996, Shiyou Li, Katie Northrup, David Creech, and Dehui Zhang CN-SX-X96-1228 (ASTC, cultivated, seeds); Yangling, 30 Dec 1996, Shiyou Li, Katie Northrup, David Creech, and Dehui Zhang CN-SX-Y-96-1230 (ASTC, cultivated, seeds). Shanghai: 28 Jul 1950, Taiyan Zhou 336 (cultivated). Sichuan (Szechuan): Aba, 2 Nov 1957, Qing Li 47195 (PE); Shujia Wang 1339 (PE); Anxian, 1,000 m, 8 Aug 1930, F. T. Wang 22190 (A); Beipei, Tianshen Bridge, 30 Aug 1956, Xiuolin Zhou and Jihua Xiong 1363 (SZ, cultivated); Chengdu, 1908, M. Le D. Legendre 271 (P), 484 (P); Chengdu, 1938, Yu Han 192 (SZ, cultivated); Chengdu, temple, $500 \mathrm{~m}, 18$ Jul 1928, Wenpei Fang 2276 (A, BM, E, P, US); Chengdu, 1200 m, 6 Aug 1930, F. T. Wang 22151 (A); Chungqing, 3 Aug 1939, Wenpei Fang 6065 (A, BM, E, K, US); Dujiangyan (Guanxian), Qingchenshan, 3 Jul 1936, Wenpei Fang 19706 (SZ, cultivated); Dujiangyan, Lingyanshan, $880 \mathrm{~m}$, disturbed mixed evergreen and deciduous forests, 21 Aug 1988, D. E. Boufford and B. Bartholomew 23958 (A, MO, PE); Dujiangyan, Qingchenshan, 650 m, 2 Nov 1955, Qing Li 47195 (SZ); Dukou, valley, 1,150 m, 16 Jun 1978, Qingshen Zhao s. n. (SZ); Emeishan (Omei Shan), Jun 1904, E. H. Wilson 4949 (A, BM, K); Emeishan, 24 Jul 1930, Wenpei Fang 4927 (E); Emeishan, 8 Jul 1930, Wenpei Fang 6428 (K); Emeishan, 23 Nov 1930, W. C. Cheng 2231 (A, E, K); Emeishan, 10 Jul 1937, S. S. Chien 5994 (E); Emeishan, Jul-Sep 1938, C. Y. Chiao and C. S. Fan 331 (E, P, US); Emeishan, 22 Oct 1939, S. C. Sun and K. Chang 1643 (A); Emeishan, 1939, Zhongwu Yao 5049 (SZ); Emeishan, Oct 1941, C. L. Chow 4884 (US); Emeishan, 500 m, 30 Jul 1928, Wenpei Fang 2299 (A, E, K); Emeishan 500 m, 14 Jul 1941, Wenpei Fang 17289 (A); Emeishan, 650 m, Jul 24 1930, Wenpei Fang 7927 (A, BM); Emeishan, 650 m, Jul 26 1938, Wenpei Fang 12595 (BM, US); Emeishan, 650 m, Jul 24 1941, Wenpei Fang 17378 (A); Emeishan, 750 m, 3 Sep 1957, Guanghui Yang 57064 (SZ); Emeishan, 800 m, 12 Aug 1938, K. N. Yin 197 (A, US); Emeishan, 850 m, 7 Aug 1938, K. N. Yin 176 (A); Emeishan, 1,000 m, 21 Aug 1938, C. Y. Chiao and C. S. Fan 675 (A, E, P); Emeishan, 1,000 m, 1940, L. Y. Tai 538 (A); Emeishan, 1,000-1,150 m, 21 Aug 1928, Wenpei Fang 3236 (E, K); Emeishan, 1,300 m, 11 Sep 1957, Guanghui Yang 57248 (SZ); Emeishan, Baoguosi, 3 May 1936, Zhongshu Qian 5454 (SZ); Emeishan, Baoguosi, 10 Jul 1937, Zhongshu Qian 5994 (SZ); Emeishan, Baoguosi, 28 Nov 1953, Jihua Xiong et al. 32146 (SZ); Emeishan,
Baoguosi, 29 Sep 1939, Wenpei Fang 13658 (SZ); Emeishan, Baoningsi, 24 Jul 1942, Chenglie Chow 6404 (SZ); Emeishan, brush, 900-1,100 m, 3 Aug 1928, Wenpei Fang 2409 (E, K, SZ); Emeishan, Cunyangdian, 1,000 m, 5 Nov 1956, Guofeng Li 53152 (SZ); Emeishan, Daesi, 25 Jul 1956, Linzhen Hu 50890 (SZ); Emeishan, Fuhusi, 510 m, 26 Aug 1957, Guanghui Yang 56928 (SZ); Emeishan, Fuhusi, 350 m, 19 Oct 1956, Guofeng Li 52789 (SZ); Emeishan, Fuhusi, 550 m, 25 Oct 1956, Guofeng Li 52939 (SZ); Emeishan, Fuhusi, 650 m, 24 Jul 1941, Wenpei Fang 17378 (SZ); Emeishan, Gaodongkou, 700 m, 29 Oct 1956, Guofeng Li 53031 (SZ); Emeishan, Guangfusi, 6 Nov 1952, Jihua Xiong et al. 33541 (SZ); Emeishan, Hungchunping, 900-1,000 m, 26 Aug 1938, H. C. Chow 8230 (A); Emeishan, Jigongsi, 560 m, 19 Sep 1956, Yuhui Tao 52257 (SZ); Emeishan, Leiyinsi, 680 m, 5 Sep 1956, Yuhui Tao 51969 (SZ); Emeishan, Maoeshi, 500 m, 14 Jul 1941, Wenpei Fang 17289 (SZ); Emeishan, Qingyinge, 25 Jul 1956, Linzhen Hu 50890 (SZ); Emeishan, Qingyinge, 28 Jul 1956, Linzhen Hu 51012 (SZ); Emeishan, roadside from Qingyinge to Liangfenggang, 22 Jul 1956, Linzhen $\mathrm{Hu} 50792$ (SZ); Emeishan, Wansingzhuang, $475 \mathrm{~m}, 17$ Oct 1941, Chenglie Chow 4884 (SZ); Huangya, Kaomiao, 1938, T. S. Chao 72 (SZ); Jiangyou, 650 m, 24 Jun 1977, Kunjun Fu 15787 (WUK); Leshan, Dafesi, 400 m, 5 Sep 1959, Zhongtian Guan 6330 (BISC); Nanchuan, Jinfeshan, 550 m, 19 Sep 1957, Guofeng Li 64279 (KUN, SZ); Nanchuan, Jinfeshan, 850 m, 22 Sep 1957, Jihua Xiong 93646 (PE, SZ); Nanchuan, Hachualu, Luchihu, C. Bock and A. Rosthorn 820 (O); Pengzhou, Bailu Xiang, 900 m, 15 Feb 1995, Shiyou Li and Wanli Zhang 941010 (NEFI); Tianjin, 850 m, 14 Sep 1963, Kejian Guan et al. 3475 (PE); Xichang, Chuanxing, 1500 m, 19 Jun 1978, Qingsheng Zhao 5414 (SZ, cultivated); Xikang, 1939, F. C. Tai and class 5313 (A). Yunnan: Anlong, 21 Jun 1960, Zhisong Zhang 5656 (BISC); Cheli, Xiao Mengyang, 1,000 m, woods, Sep 1936, Chiwu Wang 79610 (KUN); Eshan, Huanianba, 1,240 m, 5 Jul 1954, Pinyi Mao 4377 (BISC); Funing, 600 m, 14 Jun 1964, Shoucheng Wang 1002 (KUN); Guangnan, woods, 5 Oct 1935, Xipeng Ma 55854 (BISC); Hekou, Yaoshan, 1,530 m, 9 May 1966, Mingyou He and Yinggui Guan 19 (SZ); Jingdong, roadside, 1,250 m, 30 Sep 1956, Bingyun Qiou 52427 (KUN); Jingdong, roadside, $1,800 \mathrm{~m}, 24$ Oct 1939, Buqin Zhong 2040 (BISC, cultivated); Jingdong, road to Chengyuan, 1,150 m, 30 Oct 1933, Y. Tsiang 12440 (BISC); Kunming, Kunming Botanical Institute, 6 Nov 1980, Shengtang Li 80-1246 (A, cultivated); Kunming, Kunming Botanical Institute, 7 Aug 1981, James L. Reveal and James A. Duke 5669 (A, cultivated); Lancang, slope, 1,000 m, Sep 1936, Chiwu Wang 79610 (BISC); Menghong Hill and Plain, 2-12 Mar 1922, J. F. Rock 2727 (US); Qifan, park. 15 Jul 1958, Bingyun Qiou 57168 (KUN, cultivated); Sen Distrct, 1908, J. Cavalerie 2963 (E, K, P, type of Cephalanthus esquisolii Levl.); Xinping, Xiaohekou, slopes, 500-900 m, 15 Oct 1958, Sugong Wu 343 (KUN). Zhejiang (Chekiang): Danjiang, Mar 1982, Zhejiang Team 823-008 (BISC); Hangzhou, Laodongyao, 17 Jul 1959, Botanical Garden 2575 (BISC, cultivated); Jinhua, Jinhua Hospital, Jun 1970, Jinhua Hospital s. n. (PE, cultivated); Tiantaishan, 3 Nov 1963, Jianbe 2753 (SZ).

JAPAN. Honshu, Pref. Kypto, Tenonkyo Kameoka-shi, Oomoto Kameyama Botanical Garden, 21 Jul 1978, T. Sa- 
kiya 13 (A, cultivated seedling); Honshu, Pref. Kypto, Tenonkyo Kameoka-shi, Oomoto Kameyama Botanical Garden, 13 Aug 1978, Shunsuke Tsugaru 7721 (MO, cultivated).

U.S.A. California: Arcadia, Willard Hagen Nursery, 28 Aug 1962, Austin Griffiths, Jr. and Ross Goodrich 4613 (US); Chico, 700 m, 1992, USDA Genetic Resource Center 920011 (ASTC, seeds only, cultivated); Contra Costa County, Kensington, Blake Garden, 11 Sep 1969, Walter Vodden and Irja Knight 2773 (E); San Marino, 200 m, 1992, Hungtington Botanical Garden 920001 (ASTC, seeds only, cultivated). South Carolina: Summerville, $25 \mathrm{~m}$, December 1994, Edmund Cuthbert 9412001 (ASTC, seeds only, cultivated). Texas: Kingwood, 20 m, 6 Aug 1994, Shiyou Li and Paul R. Blackwell US-TX-K-94-0806001 (ASTC, cultivated); Nacogdoches, 100 m, 15 Jan 1993 Shiyou Li US-TXK-93-0115, 12 Jun 1994, Shiyou Li US-TX-K-93-0612, 5 Sep 1995, Shiyou Li US-TX-K-93-0905 (ASTC, cultivated); San Antonio, 200 m, Aug 1992, Lynn Lowrey 92820, 92821 (ASTC, cultivated).

1b. Camptotheca acuminata Decaisne var. rotundifolia Yang et Duan in Nat. Sci. J. Hunan Norm. Univ. 11(1):63-64 (1988); Li and Adair in Camptotheca acuminata Decaisne, 52, f. 13 (1994). TYPE: China. Hunan: Nanxian, Lindong Duan 1001 [holotype: HNNU! (missing); isotype as the lectotype (designated here): HNUSB!].

Common name: Yuan Ye Xi Shu (round leaf happytree).

According to the original description, this variety differs from others by having brown bark and rounded and small leaves with fewer lateral veins (4.5-6.5 cm long, 5.5-6.5 cm wide, with 4-7 lateral veins on each side). Flower characters are all in the scope of var. acuminata. No fruit has been collected. The type specimens (Lindong Duan 1001) were collected from Nanxian, Hunan in August 1981. Unfortunately, the holotype deposited in HNNU was lost during a move between buildings according to the curator of the herbarium. Also, the senior author died a few years ago eliminating the opportunity to acquire either confirmation of the original description or additional information about the variety. We designated the isotype deposited at HNUSB as the lectotype under the Article 9.9 of the International Code of Botanical Nomenclature [12].

No specimens available.

1c. Camptotheca acuminata Decaisne var. tenuifolia Fang et Soong in Act. Phytotax. Sin. 13(2):86. pl. 14, f. 3, 1975;

Fang and Zhang in Fl. Reip. Pop. Sin. 52(2):144-146, 1983; Li and Adair in Camptotheca acuminata Decaisne, 52, f. 13 (1994). TYPE: China. Guangdong: Huaiji, Bingming Zhang 20309 (holotype: BISC!; photos: ASTC!).

Common name: Bao Ye Xi Shu (tenuous leaf happytree).

The original description stated that the variety is distinguished from var. acuminata by its longer fruit $(3.0-3.2 \mathrm{~cm}$ long) and thin and smaller leaves (8-10 cm long, 4-6 cm wide, 11-12 lateral veins on each side).

According to Zipu Soong, the co-author of the variety, there is only one known specimen which was collected on November 4, 1952. Based on this specimen, Fang and Soong published the new variety in 1975. Soong stated that the authors never saw the tree in the field and did not have additional information such as habitat and distribution. In 1995, while visiting the site in Shebei Village, Luogang Community, Huaiji County, Guangdong Province, it was found that the tree from which the type specimen was collected was removed in the late 1980s and that no seedlings or other trees remained. The collector, Bingming Zhang, was the only botanist who saw the living tree. Thus, there is probably no living specimen left in that locality. In the past ten years the forest has been clearcut for crops.

The type specimen was collected in November when leaves are mature. Leaves of the type are not "tenuifolia" as described in the original description. According to the type, the leaf of var. tenuifolia is similar in shape to that in the hybrid between $C$. acuminata and $C$. lowreyana but is smaller with fewer veins. The fruit of var. tenuifolia seems more similar to $C$. lowreyana. This taxon is possibly a hybrid between $C$. acuminata and $C$. lowreyana. The DNA markers support this hypothesis.

\section{Specimen Citation}

CHINA. Guangdong: Huaiji, Luogang (Shebei Village), 4 Nov 1952, Bingming Zhang 20309 (Type: BISC!).

2. Camptotheca lowreyana S.Y. Li (Figs. 1, 2, 4, and 5) in Bull. Bot. Res. 17(3): 1997. Qin and Phengklai in Flora of China 13:301 (2007) [9]. TYPE: CHINA, Guangdong, Lianxian, You Ling Yao Pai, 18 Nov 1930, Xipeng Gao 50863 (holotype: BISC!; photos: ASTC!).

Common name: Lowrey $\underline{\mathrm{Xi}} \underline{\mathrm{Shu}}$ (Lowrey happytree).

Local names in China: Lang Dong Shu (in Huaiji of Guangdong) and Qing Yang Hua (in Lianxian of Guangdong).

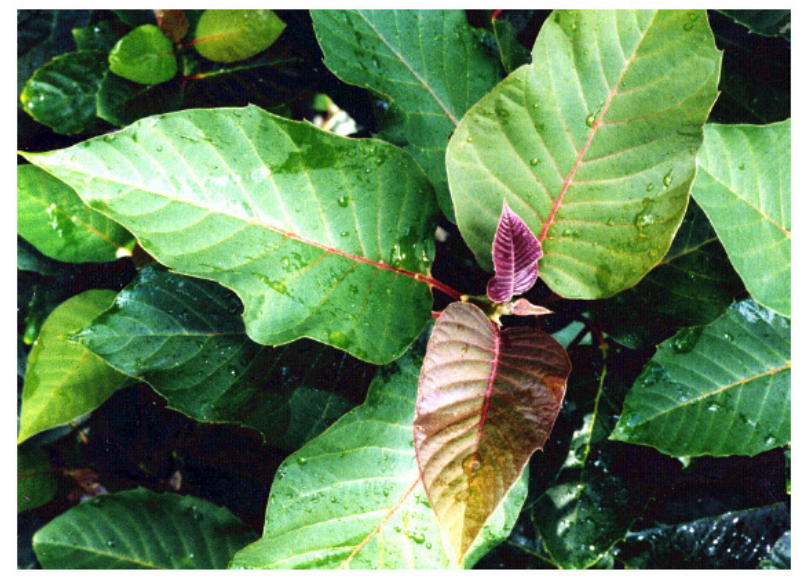

Fig. (4). Camptotheca lowreyana Li cultivated in Nacogdoches, Texas, USA.

Under natural conditions, $C$. lowreyana reaches $20 \mathrm{~m}$ in height and $120 \mathrm{~cm}$ in diameter. Bark is light gray and smooth when immature, and deeply furrowed into ridges at maturity. Leaves are deciduous, cordate or ovate, with the widest point below the blade middle, slightly pubescent, entire when mature, but serrate in seedling stage, 12(10)-19(22) cm long and 7(5)-10(13) cm wide, lower leaf surface greenish and lucid, lateral veins $14-18$ on each side. Bracts are 1.5-2.0 mm long. 
Petals are $1.2-1.5 \mathrm{~mm}$ long. The pollen is very similar to that of C. acuminata, measuring 34.4 (28.6-40.2) $\mu \mathrm{m}$ (polar axis) $\times 39.8(34.5-42.5) \mu \mathrm{m}$ (equatorial axis) in size. According to our examinations, the only significant difference between the pollen of C. acuminata and C. lowreyana is that the pollen of the latter is more oblate. Fruits are two or three thin-winged, gray-brown, smooth and lucid when dry, 26-32 (22-43) $\mathrm{mm}$ long and 5-7 mm wide. Hypocotyl is green before primary leaf appears. Cotyledons are lanceolate 2-4 cm long, about 1 $\mathrm{cm}$ wide, pinninerved, with 6-8 lateral veins on each side.

Camptotheca lowreyana differs from C. acuminata, including all three varieties, by its cordate or ovate leaves with greenish and lucid lower surface, gray-brown, smooth, lucid, and longer fruit (26-32 mm long), and pinninerved cotyledon with 4-7 lateral veins on each side. In contrast, $C$. acuminata has oval or round leaves with grayish lower surface, yellowbrown, rugose, and shorter fruit (19-25 mm long), and pinnipalmate cotyledon with 2-4 lateral veins on each side, making it distinctly different from C. lowreyana.

The species was named in honor of Mr. Lynn R. Lowrey of Anderson Landscape and Nursery in Houston, Texas (Fig. 5). Mr. Lowrey, a renowned horticulturist, played a very significant role in initiating Camptotheca studies in the United States as well as encouraging our investigations.

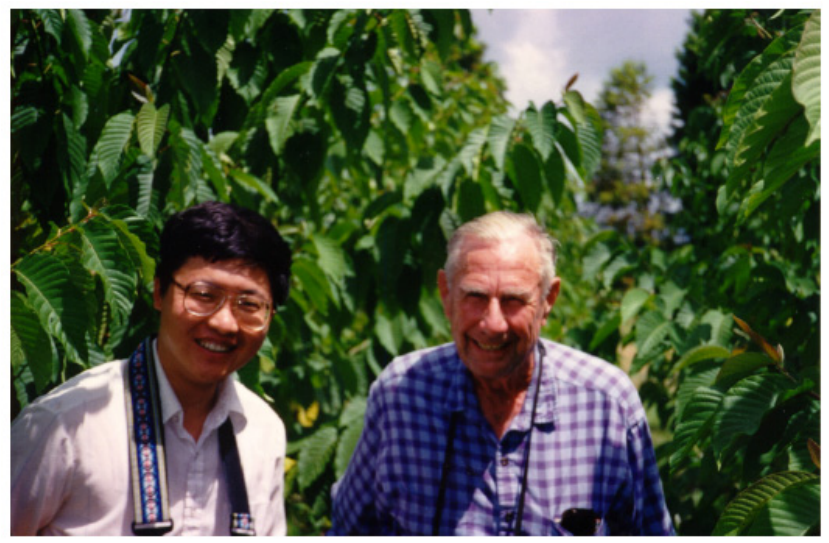

Fig. (5). Lynn Lowrey (left) and Shiyou Li in Camptotheca acuminata survey in 1994.

\section{Distribution and Ecology}

Camptotheca lowreyana is found grows in a mixed hardwood forest in Huaiji County, Guangdong. According to the specimens collected from 1930 to 1985, the species was also naturally distributed in Heping, Lianshan, Lianxian, Nanxiong, Qujiang, and Zijin of Guangdong Province, Debao of Guangxi Province, Dongan of Hunan Province, and Nanchuan of Sichuan Province, but no recent collections (after 1985) are available from these areas. The herbarium specimens collected from 1930 to 1973 indicate that the species was cultivated in Dehua of Fujian Province and Guixi, Huichang, Jingganshan of Jiangxi Province. According to our estimate based on the field survey in 1995, however, the wild populations probably number fewer than 500 mature trees. In the Dakengshan Forestry Farm and Shiying Community, Huaiji County, Guangdong, an estimated 30 mature trees were found growing along streams. Most of these appeared overmature at $15-20 \mathrm{~m}$ in height and $80-120 \mathrm{~cm}$ in diameter. Most of these 30 trees, however, were on the cut list, scheduled for harvest within the next two years. An appeal to spare them was successful. They will be retained and protected as an important genetic resource.

\section{Specimen Citation}

CHINA. Fujian: Dehua, west of the town, 1,100 m, 9 Oct 1930, Buqin Zhong 219 (BISC, cultivated). Guangdong: Heping, Liyuan (Juntung), 400 m, 12 Aug 1983, Guicai Zhang 448 (BISC); Huaiji, Dakengshan Tree Farm, 1,270 m, 4 Mar 1995, Shiyou Li and Wanli Zhang CN-GD-H-950304001 (ASTC, NEFI); Huaiji, Dakengshan Tree Farm, 1,270 m, 16 Dec 1996, Shiyou Li, Katie Northrup, David Creech, and Dehui Zhang CN-GD-H-96-1216001, 1215002, 1216003 (ASTC, seeds); Huaiji, Dakengshan Tree Farm, 1,270 m, 15 Dec 1996, Shiyou Li, Katie Northrup, David Creech, and Dehui Zhang CN-GD-H-96-1217001, 1217002, 1217003, 1217004, 121705 (ASTC, seeds); Huaiji, Lengkeng, 100 m, 11 Oct 1958, Yingguang Liu 3048 (HNNU, BISC); Huaiji, Shiying, 700 m, 5 Mar 1995, Shiyou Li and Wanli Zhang CN-GD-H-95-0305002 (ASTC, NEFI); Huaiji, Shiying, $700 \mathrm{~m}$, Yiongqian Cheng 170812 (BISC); Huaiji (Waitsap), Tangzhong, 7 Nov 1933, W. T. Tsang 23130 (A); Huaiji, Yaoshan Tree Farm, 7 Nov 1933, W. T. Tsang 23130 (BISC); Lechang, along river to Xikeng, 23 Oct 1928, Ying Jiang (Ying Tsiang) 1429 (A, BISC, E); Lechang, Xikeng, 18 Nov 1931, Xiangri Liang and Yingkun Huang 31422 (BISC, MO); Lianshan, Guohe (Da Long Shan), 200 m, 1 Oct 1945, Shaqing Chen 5529 (BISC); Lianxian, Yaoan Tree Farm, 30 Jun 1984, Nanling Team 548104 (BISC); Lianxian, You Ling Yao Pai, 18 Nov 1930, Xipeng Gao 50863 (Type: BISC; photos: ASTC); Long Tian, 27 Dec 1927, W. Y. Chun 5957 (A); Nanxiong, Maozifeng Tree Farm, 10 Aug 1974, Guangdong Wood Survey Team 400476 (BISC); Qujiang, Xiaokeng Tree Farm, 13 Aug 1985, Guicai Zhang 834 (BISC); Ranhua, 600-700 m, woods, 29 Sep 1958, Liang Deng 7778 (WUK); Yaoshan, mixed woods, 6 Oct 1936, C. Wang 40005 (A); Zijin, Jiouhe, 17 Jul 1958, Zhaofen Wei 120899 (KUN, BISC); Zijin, Yongkeng and Xiaobei, $250 \mathrm{~m}$, 25 Sep 1959, Shaoqing Chen 8386 (BISC). Guangxi: Debao, road to Tree Nursery, $500 \mathrm{~m}, 29$ Nov 1958, Zhaosai Zhang 13599 (BISC, cultivated). Hunan: Dongan, Shunhuangshan, 16 Aug 1953, Y. Liu s. n. (PE). Jiangxi: Guixi, town, 100 m, Shushen Lai 4046 (PE, cultivated). Huichang: field along rivers, 2 Jul 1958, Qiming Hu 2998 (PE, BISC, cultivated); Jinggangshan, Ciping, 730 m, 12 Oct 1954, Lingsan Yao et al. 4948 (PE, cultivated); Jinggangshan, Huangping, 7 Jul 1973, Xiangxue Yang 730450 (BISC, cultivated); Jinggangshan, Lingshan Yao et al. 4948 (PE, cultivated). Sichuan: Nanchuan, Jinfeshan, Oct 1939, C. Pei 7389 (PE).

U.S.A. Texas: Nacogdoches, 100 m, 1 Dec 1995, Shiyou Li US-TX-N-95-1201003 (ASTC, cultivated); Nacogdoches, 100 m, 25 Nov 1996, Shiyou Li, Dawn Parish, and Arron Kulhavy US-T-N-96-1125 (ADTC, cultivated, seeds).

\section{Cultivars}

\section{(1) Camptotheca lowreyana Li 'Katie' (Fig. 6)}

'Katie' is a patented cultivar distinguished by its vigorous and dense multi- branching growth habit and smallest and lanceolate or elliptic leaves with entire margins in both juve- 
nile and maturity stages [13]. The plant can grow up to $3 \mathrm{~m}$. The cultivar has significantly higher CPTs yield $(0.4778 \%$ at average, on dry weight basis) in young leaves and is more hardy and drought-tolerant than natural Camptotheca taxa [14]. It was named after Katie Northrup of Houston, Texas.

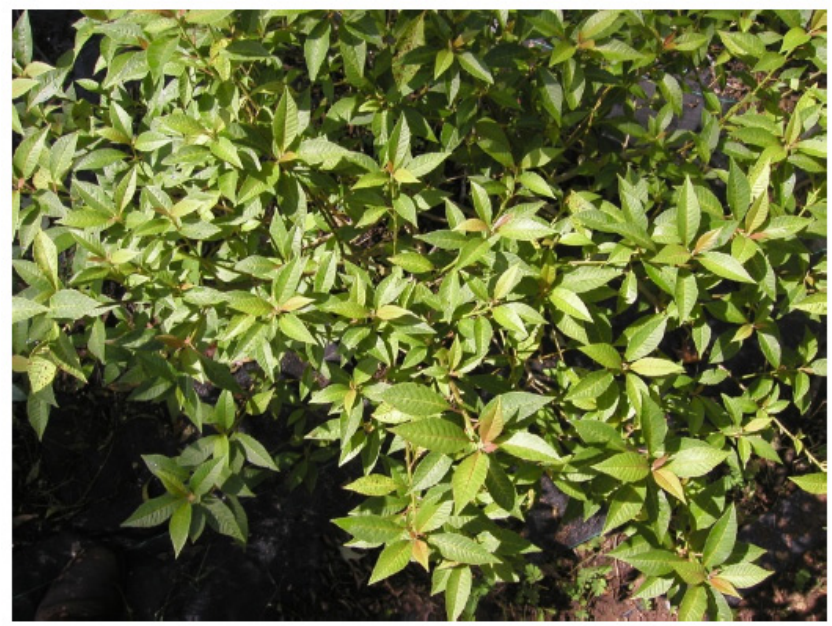

Fig. (6). Camptotheca lowreyana 'Katie'.

\section{(2) Camptotheca lowreyana Li 'CT168' (Fig. 7)}

'CT168' is a dwarf mutant of cultivar 'Katie'. Similar to 'Katie', but it is characterized by it smaller heterogeneous leaves, reduced internodes, and profuse branching [15]. It can grow up to $1 \mathrm{~m}$. The mutant has the highest CPT yield among Camptotheca taxa: $0.5890 \%$ (on dry weight basis) in young leaves at average.

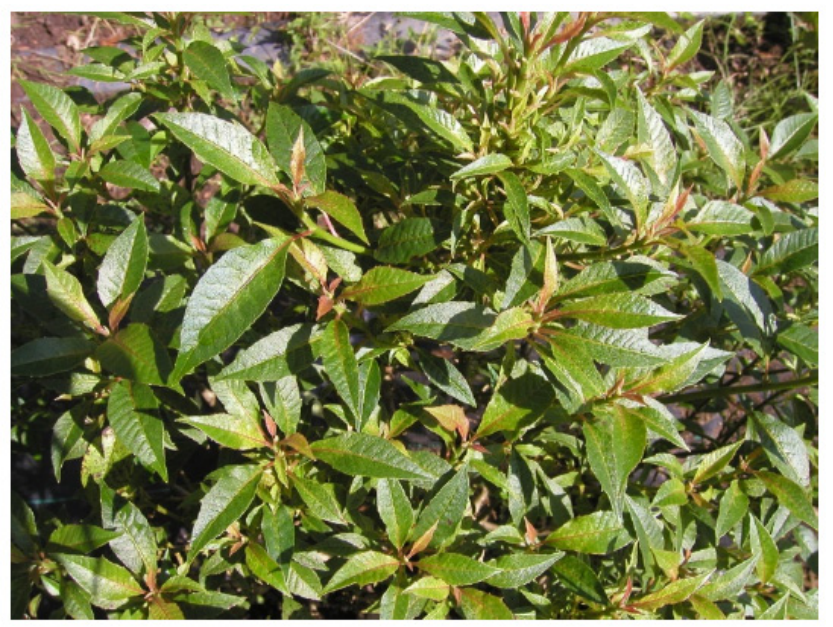

Fig. (7). Camptotheca lowreyana 'CT168'.

\section{(3) Camptotheca lowreyana Li 'Hicksii' (Fig. 8)}

A highest CPTs yield cultivar 'Hicksii' is in the process of development. This cultivar was named in honor of Mr. Jack Hicks in Lufkin, Texas for his support to the medicinal plants research. The average CPT concentration in young leaves of 'Hicksii' is $0.5537 \%$ (on dry weight basis) [14].

3. Camptotheca yunnanensis Dode Figs. (1), (2), and (9) in Bull. Soc. Bot. France LV. 651, f. c (1908). TYPE: CHINA, Yunnan, Delavay no number (holotype: P!).
Proposed common name: Yunnan Xi Shu (Yunnan happytree)

Species affinis $C$. acuminatae Decaisne et C. lowreyanae $\mathrm{Li}$, a qua differt foliis semi-deciduous elliptic, nervis lateralibus saepissime [12-15], samaris canobrunneus lucidis, longioribusque circiter 18-24 mm longis, linear cotyledon pinnatinervis.

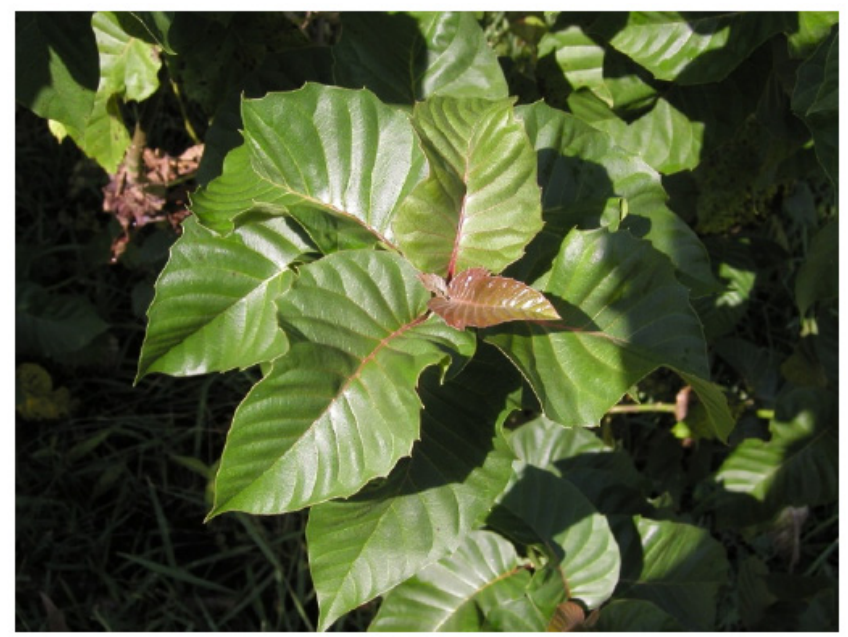

Fig. (8). Camptotheca lowreyana 'Hicksii'.

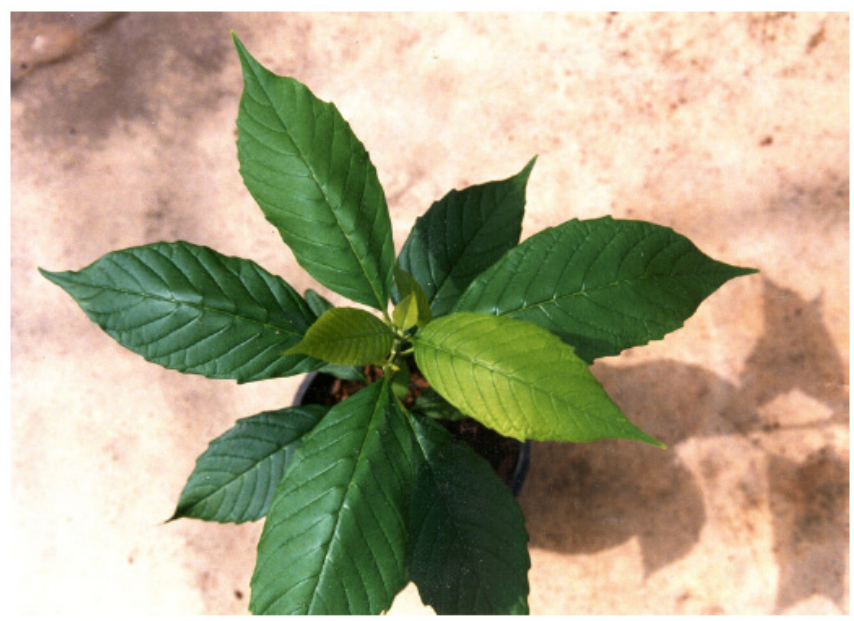

Fig. (9). Camptotheca yunnanensis Dode cultivated in Nacogdoches, Texas, USA.

Camptotheca yunnanensis was described by A. Dode in 1908 based on the specimen collected from Yunnan by Delavay (at Herbarium of Museum of Paris) in September 1888. Dode emphasized that C. yunnanensis has smaller fruit (1.5 cm long). But Wilson (1914) stated that Dode's type specimen showed immature fruits because it was collected in September. C. yunnanensis has never been studied because of its incomplete original description and no further collections. Wilson (1914) simply treated C. yunnanensis as a synonym because he believed that the characteristics of $C$. yunnanensis were within the variation range of $C$. acuminata [16]. In 1995, the author identified the living trees cultivated in Yangbi, Yunnan as C. yunnanensis according to the original fruit description. In 1997, the author found the species in Kunming City planted as street trees, and finally discovered 
wild trees in Xishuangbanna. Based on the seedlings and anatomical study, C. yunnanensis should be recognized as a species separate from C. acuminata.

Camptotheca yunnanensis grows naturally along rivers and streams in Mengyang, Xishuangbanna, Yunnan, China. The species is cultivated as street trees in Yangbi and Kunming, where it has been commonly recognized as C. acuminata. However, there are significant differences that $C$. yunnanensis distinguish from other taxa in Camptotheca: (1) semi-deciduous, ellptic leaves with 12-15 lateral veins on each side, (2) gray, smooth, lucid, thin three-winged fruits, and (3) red hypocotyl (before primary leaf appears) and linear, pinnipalmate cotyledon. According to our field observations, the leaves of C. yunnanensis are semi-deciduous under both natural and cutivated conditions, and green leaves may remain in the spring of the second year when new leaves appear. This feature of $C$. yunnanensis remained distinctive when growing together with other taxa in the same greenhouse conditions at SFASU. In addition, there is normally a spring drought in Yangbi, Yunnan, but it apparently has little or no significant influence on total seasonal tree growth. Also, according to our field tests, C. yunnanensis is less cold-hardy than other two species.

\section{Specimen Citation}

CHINA. Yunnan: Jingtong, 1,900 m, 24 Nov 1939, Minggang Li 2040 (WUK); Mengyang, Dadugang, woods along streams, 27 Dec 1996, Shiyou Li, Katie Northrup, David Creech, and Dehui Zhang CN-YN-X-96-1227 (ASTC, seeds); Kunming, 25 Dec 1996, Shiyou Li, Katie Northrup, David Creech, and Dehui Zhang CN-YN-X-96-1225 (ASTC, seeds); Simao, 1,700 m, A. Henry 13091 (A, E); Simao, 2,000 m, A. Henry 13433 (A, E); Yangbi, roadside, 1,450 m, 14 Jun 1984, Sino-American United Team 32 (A, E, KUN, US, cultivated); Yangbi, road to Xianguan, 1,800 m, 7 Aug 1963, Zhongdian Team 63-4300 (KUN, cultivated); Yangbi, road to Xianguan, 1,500 m, $23 \mathrm{Feb} 1995$, Shiyou Li and Wanli Zhang CN-YN-Y-94-022301 (ASTC, NEFI, cultivated).

U.S.A. Texas: Nacogdoches, 100 m, 1 Dec 1995, Shiyou Li US-TX-N-95-1201005 (ASTC, cultivated).

\section{CONFLICT OF INTEREST}

The authors confirm that this article content has no conflict of interest.

\section{ACKNOWLEDGEMENTS}

Declared none.

\section{PATIENT'S CONSENT}

Declared none.

\section{REFERENCES}

[1] McDade, L. A. Species concepts and problems in practice: Insight from botanical monographs. Syst. Bot., 1995, 20(4), 606-622.

[2] Mayr, E. Species concepts and definitions. In The species problem, Mayr, E., Ed. AAAS: Washington DC, 1957; pp. 371-388.

[3] Mayr, E. What is a species, and what is not? Philosophy Sci., 1996, 63, 262-277.

[4] Stuessy Plant taxonomy. 2nd ed.; Columbia University Press: New York, 2009.

[5] Cronquist, A. A integrated system of classification of flowering plants. Columbia University Press: New York, 1981.

[6] LI, S. Y. Camptotheca lowreyana, a new species of anti-cancer happytrees. Bull. Bot. Res., 1997, 17(3), 348-352.

[7] Sohma, K. Pollen morphology of the Nyssaceae, I. Nyssa and Camptotheca. Sci. Rep. Tohoku Univ. Ser. IV (Biology) 1963, 29, 389-392.

[8] Erdtman, G. Pollen morphology and plant taxonomy, angiosperms. 2nd ed.; Hafner Publishing Company: New York, London, 1966.

[9] Qin, H.; Phengklai, C. Nyssaceae. In Flora of China, Wu, Z. Y.; Raven, P. H.; Hong, D. Y., Eds. Science Press and Missouri Botanical Garden Press: Beijing, St. Louis, 2007; vol. 13 (Clusiaceae through Araliaceae).

[10] Li, L. C.; Hsu, P. S. Chromosome observations of eight species endemic to China. Acta Phytotax. Sin., 1986, 24, 157-160.

[11] Yang, Y. P.; Li, C. B. Forests of Sichuan. China Forestry Press: Beijing, 1992.

[12] Greuter, W.; Barrie, F. R.; Nurdet, H. M.; Chaloner, W. G.; Demoulin, V.; Hawksworth, D. L.; Jørgensen, P. M.; Nicolson, D. H.; Silva, P. C.; Trehane, P.; Mcneill, J. International Code of Botanical Nomenclature (Tokyo Code). Koeltz Scientific Books: Königstein, 1994.

[13] Li, S. Y. Camptotheca lowreyana cultivar named 'Katie'. U.S. Patent pp11, 959p, 2001.

[14] Li, S. Y.; Yi, Y. J.; Wang, Y. J.; Zhang, Z. Z.; Beasley, R. S. Camptothecin accumulation and variation in Camptotheca Decaisne. Planta Med., 2002, 68(11), 1010-1016.

[15] Li, S. Y.; Wang, P.; Yuan, W. Induced endogenous autotoxicity in Camptotheca. Front. Biosci., 2010, E2, 1196-1210.

[16] Li, S. Y.; Adair, K. T. Camptotheca acuminata Decaisne, Xi Shu, A Promising Anti-tumor and Anti-viral Tree for the 21st Century. Henry M. Rockwell Monograph, Stephen F. Austin State University: Nacogdoches, 1994.

Received: December 30, 2013

Revised: September 16, 2014

Accepted: September 24, 2014

(C) Shiyou Li; Licensee Bentham Open.

This is an open access article licensed under the terms of the Creative Commons Attribution Non-Commercial License (http://creativecommons.org/licenses/by-nc/3.0/) which permits unrestricted, non-commercial use, distribution and reproduction in any medium, provided the work is properly cited. 